\title{
PERCEPTION ON THE USAGE OF INFORMATION COMMUNICATION TECHNOLOGY FOR ECOTOURISM DEVELOPMENT IN NIGERIA
}

\author{
Adegboyega \\ Oyebode $^{1+}$ \\ (iD) Adebisi Ilesanmi \\ Adeyemo $^{2}$ \\ (iD) Sunday Oladipo \\ Oladeji $^{3}$
}

\author{
${ }_{1,2,3}$ Ecotourism and Wildlife Department, School of Agriculture and \\ Agricultural Technology, Federal University of Technology Akure, Nigeria. \\ 'Email:amosoyebode@gmail.com Tel: +2348108709039 \\ ${ }^{2}$ Email: bisisanmi@gmail.com Tel: +2348034746386 \\ ${ }^{3}$ Email: sooladeji@futa.edu.ng Tel:+2348030698896
}

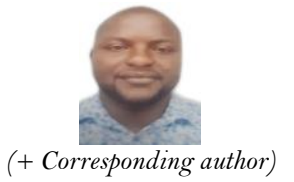

\section{Article History}

Received: 8 October 2021 Revised: 15 December 2021 Accepted: 3 January 2022 Published: 13 January 2022

\section{Keywords}

\section{Perception}

Destination

Information

Technology

Tourists

Internet

Tourism.

\begin{abstract}
This study aimed to assess the perception of tourists on the usage of information and communication technology at Old Oyo National Park, Ikogosi Warm Spring Resort and Lacampagne Tropicana by using structured questionnaire directed at 384 tourists randomly; 20 tourists at Old Oyo National Park, 150 tourists at Ikogosi Warm Spring Resort and 214 tourists at Lacampagne Tropicana. Data was analyzed and presented descriptively using tables and inferentially using one way analysis of variance (ANOVA). Results indicated that the tourists mostly made use of internet and social media at the sites. The tourists also perceived that the use of Information Communication Technology would be an innovative approach to solving some of the problems of sustainable tourism development and that use of Information Communication Technology has made work easier and faster. Furthermore, the study indicated significant differences in some socio-demographic characteristics as well as perception on the usage of ICT at the sites $(\mathrm{P}<0.05)$. Management of ecotourism sites should therefore create more awareness on the usage of other forms of information communication technology at their sites so as to further enhance tourists' satisfaction.
\end{abstract}

Contribution/Originality: This study contributes to existing literature on the usage of information communication technology and has thus provided baseline data on the advantages of completely harnessing the prowess of information communication technology applications in ecotourism sites so as to further develop the sites, while enhancing satisfaction and loyalty of tourists.

\section{INTRODUCTION}

Tourism is regarded as one of the largest industry globally which has garnered report of massive and consistent growth and contributes $9.8 \%$ to the total Gross Domestic Product of the world. Tourism is reported as a major export sector of many developing nations. Simultaneously, tourism provides employment for around two hundred and eighty million people signifying one out of eleven jobs is provided by the tourism sector. Tourism growth is evident in the record of twenty-five million tourists in 1950 which grew to a record of 1186 million tourists in 2015 (United Nations World Tourism Organization (UNWTO), 2016). Over the years, tourism industry being a greatly innovative sector, has created a lot of influential changes to the global economy (Hjalager, 2010).

As tourism has emerged as one of the greatest industries with huge economic value, transfer of information and mechanisms or strategies used in the management of information should be topnotch and of great quality (Ubavic, 
2015). The information communication revolution which is involved in all branches of business economy has also been introduced to the tourism industry which has thus provided the opportunity for tourism destinations to survive and have a winning edge in the competitiveness of the market (Brdar, 2015).

Information and communication technology is regarded as a powerful force that drives and improves the growth of the tourism sector of diverse economies, and has the capacity to develop and enhance a profit-based tourism industry (Deuchar, 2012). Also, it has been established that Information and Communication Technology significantly reduces operating costs and allows small firms and destinations to have a competitive edge globally (Arker, 2010). The competitive advantage that the Information and Communication Technology poses for tourism and hospitality firms can be achieved through unique internet marketing campaigns, continuous effective communication with diverse stakeholders as well as other strategies (Mihalič, Garbin Praničević, \& Arnerić, 2015). Generally, the continuous diversification of the usage of information and communication technologies in the tourism industry has created more competitiveness in the tourism atmosphere, which has become a crucial part of trade development (Berné, García-González, García-Uceda, \& Múgica, 2015).

Information communication technologies (ICTs) have been changing the operations of tourism industry worldwide (Bethapudi, 2013). Hence, information and communication technology is a joint platform of digital and electronic technologies providing easy communication and electronic interaction between humans and information systems (Wang \& Law, 2007). Vadi and Hildegard (2014) highlighted that tourism can generate funds for protecting natural areas, enhance local and tourist awareness of biodiversity and conservation issues as well as encourage sustainable livelihoods among local people. Furthermore, Januszewska, Jaremen, and Nawrocka (2015) studied the effects of the usage of Information and Communication Technology and found out the differences in the observed merits and challenges facing its implementation by tourism destinations. However, there is little information on the perception of usage of information and communication technology for ecotourism development in Nigeria which this study aimed to explore.

\section{METHODOLOGY}

This study was carried out at Old Oyo National Park managed by the Federal Government of Nigeria located within coordinates $7.850171^{\circ} \mathrm{N}$ and $3.911465^{\circ} \mathrm{E}$, Ikogosi Warm Spring managed by Ekiti State government located within coordinates $7.590804^{\circ} \mathrm{N}$ and $4.980059^{\circ} \mathrm{E}$ and Lacampagne Tropicana managed privately located within coordinates $6.3926^{\circ} \mathrm{N}$ and $4.1865^{\circ} \mathrm{E}$ (see Figure 1). The target population for this study were tourists of the sites and Krejcie and Morgan (1970) determination of sample size was used to proportionately select the twenty visitors at Old Oyo National Park, one hundred and fifty tourists at Ikogosi Warm Spring Resort and two hundred and fourteen tourists at Lacampagne Tropicana making a total of three hundred and eighty-four tourists. This study made use of relevant literatures to construct questions in the questionnaire. Data was obtained across the three sites from January to June, 2021. Data was collated and analyzed using Statistical Package for Social Science version 23 and results were presented descriptively using frequency, percentage and tables. Inferentially, Analysis of Variance (One-Way ANOVA) was used to test the significant difference in socio-demographic characteristics of tourists in the sites as well as their perception on the usage of information Communication Technology at the sites.

\section{RESULTS}

\subsection{Socio-Demographic Characteristics of Tourists}

Table 1 reveals the socio-demographic characteristics of the tourists at Old Oyo National Park, Ikogosi Warm Spring Resort and Lacampagne Tropicana. At Old Oyo National Park, majority of the tourists were female (75\%), between the ages of 20-30 years (85\%), single (95\%), students (90\%) with tertiary education (95\%). Highest percentage of the tourists have income below 10,000 (40\%) and were Christians (95\%). 


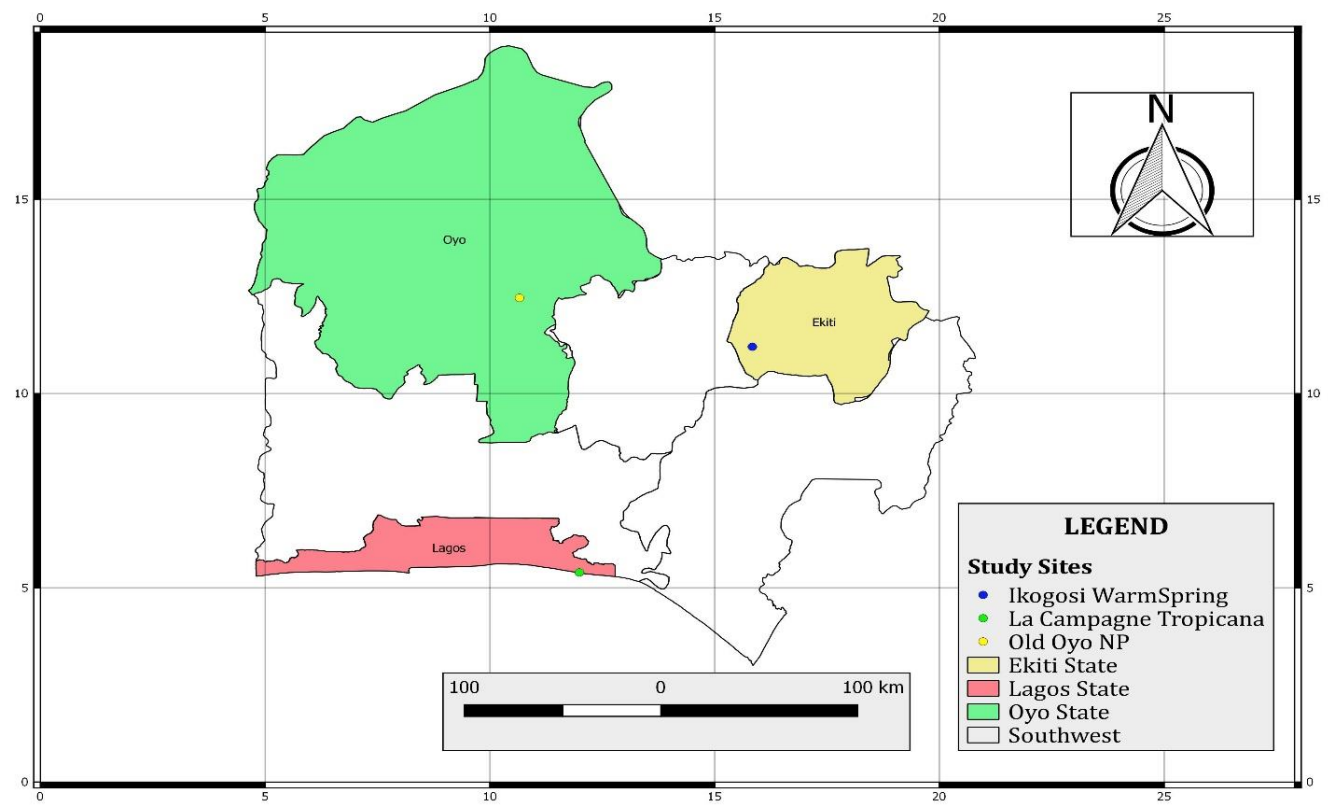

Figure 1. Map of Southwest Nigeria showing the study areas.

Table 1. Socio-demographic characteristics of tourists.

\begin{tabular}{|c|c|c|c|c|c|c|}
\hline \multirow[t]{2}{*}{ Variables } & \multicolumn{2}{|c|}{ Old Oyo National park } & \multicolumn{2}{|c|}{$\begin{array}{c}\text { Ikogosi Warm Spring } \\
\text { Resort }\end{array}$} & \multicolumn{2}{|c|}{ Lacampagne Tropicana } \\
\hline & $\begin{array}{c}\text { Frequency } \\
(20)\end{array}$ & $\begin{array}{c}\text { Percentage } \\
(\%)\end{array}$ & $\begin{array}{c}\text { Frequency } \\
(150)\end{array}$ & $\begin{array}{c}\text { Percentage } \\
(\%)\end{array}$ & $\begin{array}{c}\text { Frequency } \\
(214)\end{array}$ & $\begin{array}{c}\text { Percentage } \\
(\%)\end{array}$ \\
\hline \multicolumn{7}{|l|}{$\overline{\text { Sex }}$} \\
\hline Male & 5 & 25 & 136 & 90.7 & 107 & 50 \\
\hline Female & 15 & 75 & 14 & 9.3 & 107 & 50 \\
\hline \multicolumn{7}{|l|}{ Age } \\
\hline Below 20 & 2 & 10 & 15 & 10 & 17 & 7.9 \\
\hline $20-30$ & 17 & 85 & 135 & 90 & 129 & 60.3 \\
\hline $31-40$ & $\mathrm{O}$ & $\mathrm{O}$ & 0 & $\mathrm{O}$ & 52 & 24.3 \\
\hline $41-50$ & 1 & 5 & $\mathrm{O}$ & $\mathrm{O}$ & 16 & 7.5 \\
\hline \multicolumn{7}{|l|}{ Marital status } \\
\hline Single & 19 & 95 & 135 & 90 & 161 & 75.2 \\
\hline Married & 1 & 5 & 15 & 10 & 53 & 24.8 \\
\hline \multicolumn{7}{|l|}{ Occupation } \\
\hline Farmer & 1 & 5 & 0 & 0 & 0 & 0 \\
\hline Entrepreneur & 1 & 5 & 15 & 10 & 117 & 54.7 \\
\hline Student & 18 & 90 & 135 & 90 & 17 & 7.9 \\
\hline Artisan & $\mathrm{O}$ & 0 & $\mathrm{O}$ & $\mathrm{O}$ & 62 & 29 \\
\hline \multicolumn{7}{|l|}{ Education } \\
\hline Primary & 1 & 5 & 23 & 15.3 & 8 & 3.7 \\
\hline Secondary & $\mathrm{O}$ & $\mathrm{O}$ & $\mathrm{O}$ & $\mathrm{O}$ & 20 & 9.3 \\
\hline Tertiary & 19 & 95 & 127 & 84.7 & 186 & 86.9 \\
\hline \multicolumn{7}{|l|}{ Income } \\
\hline Below 10,000 & 8 & 40 & 0 & $\mathrm{O}$ & O & 0 \\
\hline 10,000- 19,999 & 5 & 25 & 15 & 10 & 18 & 8.4 \\
\hline ₹20,000- $\$ 39,999$ & 4 & 20 & 61 & 40.7 & 18 & 8.4 \\
\hline \40,000-\$59,999 & $\mathrm{O}$ & $\mathrm{O}$ & 15 & 10 & 35 & 16.4 \\
\hline 丹60,000- $¥ 79,999$ & $\mathrm{O}$ & $\mathrm{O}$ & 14 & 9.3 & 9 & 4.2 \\
\hline$\$ 80,000-\$ 99,999$ & 0 & $\mathrm{O}$ & 30 & 20 & 35 & 16. \\
\hline Above 100,000 & 3 & 15 & 15 & 10 & 99 & 46.3 \\
\hline \multicolumn{7}{|l|}{ Religion } \\
\hline Christianity & 19 & 95 & 135 & 90 & 177 & 82.7 \\
\hline Islam & 1 & 5 & 15 & 10 & 29 & 13.6 \\
\hline Traditional worshiper & 0 & $\mathrm{O}$ & 0 & $\mathrm{O}$ & 8 & 3.7 \\
\hline
\end{tabular}


At Ikogosi Warm Spring Resort, majority of the tourists were males (90.7\%) between the ages of 20-30 years $(90 \%)$, single $(90 \%)$, and student $(90 \%)$ with tertiary education $(84.7 \%)$. Highest percentage of the tourists have income range of $\$ 20,000-\$ 39,999$ (40.7\%) and were Christians (90\%). At Lacampagne Tropicana, male and female tourists were of equal number (50\% each). Majority of the tourists were between the ages of 20-30 years (60.3\%), singles $(75.2 \%)$, and entrepreneur $(54.7 \%)$ with tertiary education $(86.9 \%)$. Also, highest percentage of the tourists have income above 100,000 (46.3\%) and were Christians (82.7\%).

\subsection{Level of Usage of Information Communication Technology (ICT)}

Table 2 reveals the level of usage of ICT applications at Old Oyo National Park. Internet (55\%) and Social media (50\%) have high usage at the site. Table 3 reveals social media (20\%) has high usage at Ikogosi Warm Spring Resort. Also, Table 4 reveals social media (42.1\%) has high usage at Lacampagne Tropicana.

Table 2. Level of usage of ICT at Old Oyo National Park.

\begin{tabular}{|c|c|c|c|c|}
\hline ICT based tools & High & Medium & Low & Not Used \\
\hline Geographical Information System & $6(30 \%)$ & $12(60 \%)$ & $1(5 \%)$ & $1(5 \%)$ \\
\hline Computer simulation & $3(15 \%)$ & $11(55 \%)$ & $4(20 \%)$ & $2(10 \%)$ \\
\hline Tourism Information System & $8(40 \%)$ & $11(55 \%)$ & $1(5 \%)$ & $\mathrm{O}(\mathrm{O} \%)$ \\
\hline Destination Management System & $\mathrm{O}(\mathrm{O} \%)$ & $18(90 \%)$ & $1(5 \%)$ & $1(5 \%)$ \\
\hline Environment Management Information System & $3(15 \%)$ & $12(60 \%)$ & $3(15 \%)$ & $2(10 \%)$ \\
\hline Economic Impact Analysis Software & $2(10 \%)$ & $14(70 \%)$ & $3(15 \%)$ & $1(5 \%)$ \\
\hline Virtual Tourism & $7(35 \%)$ & $9(45 \%)$ & $3(15 \%)$ & $1(5 \%)$ \\
\hline Location-based services & $\mathrm{O}(\mathrm{O} \%)$ & $11(55 \%)$ & $8(40 \%)$ & $1(5 \%)$ \\
\hline eRating System & $1(5 \%)$ & $10(50 \%)$ & $8(40 \%)$ & $1(5 \%)$ \\
\hline Internet & $11(55 \%)$ & $4(20 \%)$ & $4(20 \%)$ & $1(5 \%)$ \\
\hline Social media (Twitter, facebook, whatsapp, Instagram, etc) & $10(50 \%)$ & $4(20 \%)$ & $5(25 \%)$ & $1(5 \%)$ \\
\hline Carbon Calculators & $1(5 \%)$ & $7(35 \%)$ & $7(35 \%)$ & $5(25 \%)$ \\
\hline
\end{tabular}

Table 3. Level of usage of ICT at Ikogosi warm spring resort.

\begin{tabular}{|c|c|c|c|c|}
\hline ICT based tools & High & Medium & Low & Not Used \\
\hline Geographical Information System & $15(10 \%)$ & $0(0 \%)$ & $29(19.3 \%)$ & $106(70.7 \%)$ \\
\hline Computer simulation & $15(10 \%)$ & $\mathrm{O}(\mathrm{O} \%)$ & $\mathrm{O}(\mathrm{O} \%)$ & $135(90 \%)$ \\
\hline Tourism Information System & $15(10 \%)$ & $0(0 \%)$ & $29(19.3 \%)$ & $106(70.7 \%)$ \\
\hline Destination Management System & $15(10 \%)$ & $\mathrm{O}(\mathrm{O} \%)$ & $\mathrm{O}(\mathrm{O} \%)$ & $135(90 \%)$ \\
\hline Environment Management Information System & $15(10 \%)$ & $29(19.3 \%)$ & $\mathrm{O}(\mathrm{O} \%)$ & $106(70.7 \%)$ \\
\hline Economic Impact Analysis Software & $\mathrm{O}(\mathrm{O} \%)$ & $\mathrm{O}(\mathrm{O} \%)$ & $15(10 \%)$ & $135(90 \%)$ \\
\hline Virtual Tourism & $\mathrm{O}$ & $15(10 \%)$ & $15(10 \%)$ & $120(80 \%)$ \\
\hline Location-based services & $14(9.3 \%)$ & $15(10 \%)$ & $\mathrm{O}(\mathrm{O} \%)$ & $121(80.7 \%)$ \\
\hline eRating System & $15(10 \%)$ & $\mathrm{O}(0 \%)$ & $14(9.3 \%)$ & $121(80.7 \%)$ \\
\hline Internet & $\mathrm{O}(\mathrm{O} \%)$ & $29(19.3 \%)$ & $15(10 \%)$ & $106(70.7 \%)$ \\
\hline Social media (Twitter, facebook, whatsapp, Instagram, etc) & $30(20 \%)$ & $14(9.3 \%)$ & $\mathrm{O}(\mathrm{O} \%)$ & $106(70.7 \%)$ \\
\hline Carbon Calculators & $15(10 \%)$ & $15(10 \%)$ & $\mathrm{O}(\mathrm{O} \%)$ & $120(80 \%)$ \\
\hline
\end{tabular}

Table 4. Level of usage of ICT at Lacampagne Tropicana.

\begin{tabular}{|c|c|c|c|c|}
\hline ICT based tools & High & Medium & Low & Not Used \\
\hline Geographical Information System & $47(22 \%)$ & $27(12.6 \%)$ & $43(20.1 \%)$ & $97(45.3 \%)$ \\
\hline Computer simulation & $37(17.3 \%)$ & $53(24.8 \%)$ & $27(12.6 \%)$ & $97(45.3 \%)$ \\
\hline Tourism Information System & $65(30.4 \%)$ & $34(15.9 \%)$ & $26(12.1 \%)$ & $89(41.6 \%)$ \\
\hline Destination Management System & $37(17.3 \%)$ & $35(16.4 \%)$ & $45(21 \%)$ & $97(45.3 \%)$ \\
\hline Environment Management Information System & $29(13.6 \%)$ & $35(16.4 \%)$ & $44(20.6 \%)$ & $106(49.5 \%)$ \\
\hline Economic Impact Analysis Software & $29(13.6 \%)$ & $26(12.1 \%)$ & $53(24.8 \%)$ & $106(49.5 \%)$ \\
\hline Virtual Tourism & $35(16.4 \%)$ & $47(22 \%)$ & $26(12.1 \%)$ & $106(49.5 \%)$ \\
\hline Location-based services & $19(8.9 \%)$ & $55(25.7 \%)$ & $35(16.4 \%)$ & $105(49.1 \%)$ \\
\hline eRating System & $45(21 \%)$ & $37(17.3 \%)$ & $34(15.9 \%)$ & $98(45.8 \%)$ \\
\hline Internet & $73(34.1 \%)$ & $8(3.7 \%)$ & $34(15.9 \%)$ & $99(46.3 \%)$ \\
\hline Social media (Twitter, facebook, whatsapp, Instagram, etc) & $90(42.1 \%)$ & $18(8.4 \%)$ & $17(7.9 \%)$ & $89(41.6 \%)$ \\
\hline Carbon Calculators & $46(21.5 \%)$ & $37(17.3 \%)$ & $25(11.7 \%)$ & $106(49.5 \%)$ \\
\hline
\end{tabular}




\subsection{Perception on Usage of Information Communication Technology (ICT)}

Table 5 reveals the tourists perception about the usage of ICT at Old Oyo National Park. "The use of ICT will be an innovative approach to solving some of the problems of sustainable tourism development" had the highest mean (4.55). Table 6 reveals "Use of ICT applications have made my work easier and faster" had the highest mean at Ikogosi Warm Spring Resort (4.41). Table 7 reveals "The use of ICT will be an innovative approach to solving some of the problems of sustainable tourism development" and "Use of ICT applications have made my work easier and faster" both had the highest mean at Lacampagne Tropicana (4.04).

Table 5.Tourist's perception of usage of ICT at Old Oyo national park.

\begin{tabular}{l|c|c|c|c|c|c|c}
\hline Variables & SA & A & N & D & SD & Mean & St. D \\
\hline $\begin{array}{l}\text { The use of ICT will be an innovative } \\
\text { approach to solving some of the } \\
\text { problems of sustainable tourism } \\
\text { development. }\end{array}$ & & & & & & & \\
\hline $\begin{array}{l}\text { The use of ICT has led to the better } \\
\text { management of the sustainable } \\
\text { tourism development of my } \\
\text { destination }\end{array}$ & $9(45 \%)$ & $8(40 \%)$ & $2(10 \%)$ & $0(0 \%)$ & $1(5 \%)$ & 4.20 & 1.005 \\
$\begin{array}{l}\text { ICT applications are usually difficult } \\
\text { to use }\end{array}$ & $4(20 \%)$ & $3(15 \%)$ & $6(30 \%)$ & $5(25 \%)$ & $2(10 \%)$ & 3.10 & 1.294 \\
\hline $\begin{array}{l}\text { Use of ICT applications have made } \\
\text { my work easier and faster }\end{array}$ & $12(60 \%)$ & $6(30 \%)$ & $1(5 \%)$ & $0(0 \%)$ & $1(5 \%)$ & 4.40 & 0.995 \\
\hline $\begin{array}{l}\text { Use of ICT will reduce the number } \\
\text { of staff needed to carry out activities } \\
\text { at the site }\end{array}$ & $7(35 \%)$ & $9(45 \%)$ & $3(15 \%)$ & $1(5 \%)$ & $0(0 \%)$ & 4.10 & 0.852 \\
\hline $\begin{array}{l}\text { Use of ICT will require more funds } \\
\text { in order to make it effective }\end{array}$ & $7(35 \%)$ & $12(60 \%)$ & $1(5 \%)$ & $0(0 \%)$ & $0(0 \%)$ & 4.30 & 0.571 \\
\hline
\end{tabular}

Keys: SA- Strongly Agree, A- Agree, N-Neutral, D- Disagree, SD- Strongly Disagree.

Source: Field Survey, 2021.

Table 6. Tourist's perception of usage of ICT at Ikogosi Warm Spring Resort.

\begin{tabular}{l|c|c|c|c|c|c|c}
\hline Variables SA & A & N & D & SD & Mean & St. D \\
\hline $\begin{array}{l}\text { The use of ICT will be an } \\
\text { innovative approach to solving } \\
\text { some of the problems of } \\
\text { sustainable tourism } \\
\text { development. }\end{array}$ & & & & & & & \\
\hline $\begin{array}{l}\text { The use of ICT has led to the } \\
\text { better management of the } \\
\text { sustainable tourism } \\
\text { development of my destination }\end{array}$ & $61(40.7 \%)$ & $30(20 \%)$ & $44(29.3 \%)$ & $0(0 \%)$ & $15(10 \%)$ & 3.81 & 1.255 \\
\hline $\begin{array}{l}\text { ICT applications are usually } \\
\text { difficult to use }\end{array}$ & $76(50.7 \%)$ & $15(10 \%)$ & $29(19.3 \%)$ & $15(10 \%)$ & $15(10 \%)$ & 3.81 & 1.407 \\
\hline $\begin{array}{l}\text { Use of ICT applications have } \\
\text { made my work easier and } \\
\text { faster }\end{array}$ & $91(60.7 \%)$ & $30(20 \%)$ & $29(19.3 \%)$ & $0(0 \%)$ & $0(0 \%)$ & 4.41 & 0.796 \\
\hline $\begin{array}{l}\text { Use of ICT will reduce the } \\
\text { number of staff needed to carry } \\
\text { out activities at the site }\end{array}$ & $76(50.7 \%)$ & $30(20 \%)$ & $29(19.3 \%)$ & $0(0 \%)$ & $15(10 \%)$ & 4.01 & 1.269 \\
\hline $\begin{array}{l}\text { Use of ICT will require more } \\
\text { funds in order to make it } \\
\text { effective }\end{array}$ & $76(50.7 \%)$ & $45(30 \%)$ & $29(19.3 \%)$ & $0(0 \%)$ & $0(0 \%)$ & 4.31 & 0.778 \\
\hline
\end{tabular}

Keys: SA- Strongly Agree, A- Agree, N-Neutral, D- Disagree, SD- Strongly Disagree.

Source: Field Survey, 2021. 
Table 7. Tourist's perception of usage of ICT at Lacampagne Tropicana.

\begin{tabular}{|c|c|c|c|c|c|c|c|}
\hline Variables & $\mathbf{S A}$ & A & $\mathbf{N}$ & D & SD & Mean & St.D \\
\hline $\begin{array}{l}\text { The use of ICT will be } \\
\text { an innovative approach } \\
\text { to solving some of the } \\
\text { problems of sustainable } \\
\text { tourism development. }\end{array}$ & $91(42.5 \%)$ & $65(30.4 \%)$ & $42(19.6 \%)$ & $8(3.7 \%)$ & $8(3.7 \%)$ & 4.04 & 1.054 \\
\hline $\begin{array}{l}\text { The use of ICT has led } \\
\text { to the better } \\
\text { management of the } \\
\text { sustainable tourism } \\
\text { development of my } \\
\text { destination }\end{array}$ & $64(29.9 \%)$ & $63(29.4 \%)$ & $50(23.4 \%)$ & $29(13.6 \%)$ & $8(3.7 \%)$ & 3.68 & 1.147 \\
\hline $\begin{array}{l}\text { ICT applications are } \\
\text { usually difficult to use }\end{array}$ & $10(4.7 \%)$ & $36(16.8 \%)$ & $60(28 \%)$ & $47(22 \%)$ & $61(28.5 \%)$ & 2.47 & 1.201 \\
\hline $\begin{array}{l}\text { Use of ICT applications } \\
\text { have made my work } \\
\text { easier and faster }\end{array}$ & $85(39.7 \%)$ & $52(24.3 \%)$ & $77(36 \%)$ & $\mathrm{O}(\mathrm{O} \%)$ & $\mathrm{O}(\mathrm{O} \%)$ & 4.04 & 0.871 \\
\hline $\begin{array}{l}\text { Use of ICT will reduce } \\
\text { the number of staff } \\
\text { needed to carry out } \\
\text { activities at the site }\end{array}$ & $53(24.8 \%)$ & $66(30.8 \%)$ & $68(31.8 \%)$ & $8(3.7 \%)$ & $19(8.9 \%)$ & 3.59 & 1.162 \\
\hline $\begin{array}{l}\text { Use of ICT will require } \\
\text { more funds in order to } \\
\text { make it effective }\end{array}$ & $70(32.7 \%)$ & $48(22.4 \%)$ & $52(24.3 \%)$ & $24(11.2 \%)$ & $20(9.3 \%)$ & 3.58 & 1.300 \\
\hline
\end{tabular}

Keys: SA- Strongly Agree, A- Agree, N-Neutral, D- Disagree, SD- Strongly Disagree.

Source: Field Survey, 2021

\subsection{Difference in Socio-Demographic Characteristics and Perception, Due To ICT}

Table 8 reveals there are significant differences among gender, age, marital status, occupation, income, religion, perception of the usage of ICT facilities at the sites $(\mathrm{P}<0.05)$.

Table 8. Difference in socio-demographic characteristics, perception, satisfaction and revisit intention due to ICT at the sites.

\begin{tabular}{l|c|c|c|c}
\hline Variables & Mean square & F & Sig. & Decision \\
\hline Gender & 8.945 & 48.726 & $0.000^{* *}$ & Significant \\
\hline Age & 7.717 & 22.356 & $0.000^{* *}$ & Significant \\
\hline Marital Status & 1.139 & 7.987 & $0.000^{* *}$ & Significant \\
\hline Occupation & 7.466 & 9.038 & $0.000^{* *}$ & Significant \\
\hline Education & 0.994 & 2.967 & 0.053 & Not Significant \\
\hline Income & 131.723 & 45.163 & $0.000^{* *}$ & Significant \\
\hline Religion & 0.661 & 3.818 & $0.023^{*}$ & Significant \\
\hline Perception & 13.361 & 24.530 & $0.000^{* *}$ & Significant \\
\hline Satisfaction & 14.639 & 9.876 & $0.000^{* *}$ & Significant \\
\hline Revisit intention & 9.821 & 7.087 & $0.001^{* *}$ & Significant \\
\hline
\end{tabular}

Note: $* * \mathrm{P}<0.01, * \mathrm{P}<0.05$

\section{DISCUSSION}

There was a close mixture of male and female tourists at the sites with highest percentage being females at Old Oyo National park as supported by Karanikola, Tampakis, Tsantopoulos, and Digbasani (2014) who reported more females in their study but however contradicts majority being males at Ikogosi Warm Spring Resort. This study recorded a gender balance at Lacampagne Tropicana. Majority of the tourists were within the age range of 20-30 years signifying they have the strength for tourism activities. Most of the tourists were also single with majority of the tourists at Old Oyo National Park and Ikogosi Warm Spring Resort being students which could be due to the fact that the sites supports research activities while majority of the tourists at Lacampagne Tropicana were entrepreneurs. The prime ages of these visitors who were primarily singles, students and entrepreneurs suggests 
that they are economically viable to spend money on leisure and recreation as opined by Ogunbodede (2012). Majority of the tourists had tertiary education which depicts that they have the required knowledge to participate in this research. Majority of the tourists at Old Oyo National Park and Ikogosi Warm Spring resort had a low income while the tourists at Lacampagne Tropicana had high income. This is consistent with the study by Phumsathan (2011) that visitors' responses to physical conditions were highly influenced by education levels and income. Lacampagne Tropicana being a private establishment is more expensive to patronize than Old Oyo National Park and Ikogosi Warm Spring Resort being federal government and state government establishments respectively.

The tourists opined that internet and social media had the highest level of usage at the sites. Internet and Social media are the most popular forms of Information Communication Technology even though these tourist sites can play a major role in the awareness of other forms of information Communication Technology. The increased use of internet is supported by Bhat and Shah (2014) stating that e-marketing for tourism has been of paramount importance, especially with the explosive growth in new technologies and the increasing use of the Internet. Also, this study is in line with research by Karimidizboni (2013) who examined the role of information technology in the tourism industry in Iran by presenting some solutions about it. Due to popularity of internet demand, many tourist organizations, such as hotels, airplanes, and travel agencies, have changed by applying the Internet as an important part of communication and marketing strategies. Searching Information that is important part of buying decisionmaking process, evolved as an internet achievement. ICT not only reduces the risks of receiving and uncertainty, but also increases the quality of travel.The tourists also perceived that the use of Information Communication Technology (ICT) will be an innovative approach to solving some of the problems of sustainable tourism development as supported by Deuchar (2012) that Information and communication technology is considered a powerful driver for the development of the tourism sector of any economy, and has the potential to build a yieldbased tourism industry. The tourists also perceived that the use of Information Communication Technology has made work easier and faster. Works are now easy to do and even tourists can check sites on the internet before coming to patronize and a lot of problem can be resolved through these means as supported by Ogbu, Idris, and Ijagbemi (2011) who analyzed how ICT can better improve the tourism sector in Nigeria. They demonstrated various ways by which ICTs have been adapted for the course in tourism. In their work, it was revealed that almost every tourism products can be sold online without the consumer necessarily visiting the place before making any choice since tourism products are not already manufactured goods. Booking of flights and hotel reservations can be done online through e-mail, telephone calls and other internet services thereby helping to reduce if not remove entirely the time wasting processes of the old system.

\section{CONCLUSION}

This study aimed to find out tourists perception of the use of Information Communication Technology and concludes that the tourists have made use of social media and internet services available at the sites representing the highest form of Information and Communication Technology available at the sites. The tourists also perceived that the use of Information Communication Technology will be an innovative approach to solving some of the problems of sustainable tourism development and that use of Information Communication Technology has made work easier and faster. Management of ecotourism sites should therefore create more awareness on the usage of other forms of information communication technology at their sites so as to further enhance tourists' satisfaction.

Funding: This study received no specific financial support.

Competing Interests: The authors declare that they have no competing interests.

Acknowledgement: All authors contributed equally to the conception and design of the study.

\section{REFERENCES}

Arker, D. (2010). Building strong brands. SMQ (6). New York: The Free Press. 
Berné, C., García-González, M., García-Uceda, M. E., \& Múgica, J. M. (2015). The effect of ICT on relationship enhancement and performance in tourism channels. Tourism Management, 48, 188-198. Available at: https://doi.org/10.1016/j.tourman.2014.04.012.

Bethapudi, A. (2013). The role of ICT in tourism industry. Journal of Applied Economics and Business, 1(4), 67-79.

Bhat, S., \& Shah, M. (2014). Diffusion of internet technology in the tourism sector: An empirical study. Journal of Transnational Management, 19, 152-164. Available at: https://doi.org/10.1080/15475778.2014.904674.

Brdar, I. (2015). The impact of globalization on the development of tourism in Serbia. Belgrade: Singidunum University, Department of Postgraduate Studies and International Cooperation.

Deuchar, C. (2012). Small tourism enterprise network formation in rural destinations: Integrating ICT and community in Western Southland New Zealand. Doctoral Thesis, Auckland University of Technology.

Hjalager, A.-M. (2010). A review of innovation research in tourism. Tourism Management, 31(1), 1-12.

Januszewska, M., Jaremen, D., \& Nawrocka, E. (2015). The effects of the use of ICT by tourism enterprises. Zeszyty Naukowe Uniwersytetu Szczecińskiego. Service Management, 16(2), 65-73. Available at: https://doi.org/10.18276/smt.2015.16-07.

Karanikola, P., Tampakis, S., Tsantopoulos, G., \& Digbasani, C. (2014). The public zoo as recreation and environmental education area: Visitor's perceptions and management implications. WSEAS Transactions on Environment and Development, $10(1), 2-10$.

Karimidizboni, R. (2013). The impact of ICT on tourism industry in Iran. Interdisciplinary Journal of Contemporary Research in Business, 4(11), 680-685.

Krejcie, R. V., \& Morgan, D. W. (1970). Determining sample size for research activities. Educational and Psychological Measurement, 30(3), 607-610.

Mihalič, T., Garbin Praničević, D., \& Arnerić, J. (2015). The changing role of ICT competitiveness: The case of the Slovenian hotel sector. Economic Research, 28(1), 367-383.

Ogbu, S., Idris, S., \& Ijagbemi, A. (2011). Information and communication technology (ICT): A veritable tool for tourism development in Nigeria. Paper presented at the In Nigeria Computer Society (NCS): 10th International Conference.

Ogunbodede, E. (2012). Patronage pattern of tourists to Idanre hills and its implications for tourism development in Nigeria. Journal of Environmental Research and Development, 6(3A), 908-915.

Phumsathan, S. (2011). Environmental impacts of tourism in Khao Yai national park, Thailand. Doctoral Dissertation, Texas A \& M University.

Ubavic, P. (2015). Informational resources management in tourism. Economics, 61(1), 161-171.

United Nations World Tourism Organization (UNWTO). (2016). United Nations world tourism organization study on online guest reviews and hotel classification systems: an integrated approach. Service Science, 8(2), 139-151.

Vadi, V., \& Hildegard, E. G. S. S. (2014). Art, cultural heritage and the market, ethical and legal issues. Hildegard New York Dordrecht London: Springer.

Wang, D., \& Law, F. Y. T. (2007). Impacts of information and communication technologies (ICT) on time use and travel behavior: A structural equations analysis. Transportation, 34(4), 513-527.

Views and opinions expressed in this article are the views and opinions of the author(s), Journal of Tourism Management Research shall not be responsible or answerable for any loss, damage or liability etc. caused in relation to/arising out of the use of the content. 